\title{
Five New Alkaloids from Cephalotaxus lanceolata and C. fortunei var. alpina
}

\author{
Ling Ni $\cdot$ Xiu-Hong Zhong $\cdot$ Jie Cai $\cdot$ \\ Mei-Fen Bao $\cdot$ Bing-Jie Zhang $\cdot$ Jing Wu $\cdot$ \\ Xiang-Hai Cai
}

Received: 22 January 2016/Accepted: 13 March 2016/Published online: 26 March 2016

(c) The Author(s) 2016. This article is published with open access at Springerlink.com

\begin{abstract}
Five new alkaloids (1-5) were isolated from the leaves and twigs of Cephalotaxus lanceolata and C. fortunei var. alpina along with 24 known alkaloids. The new structures were elucidated based on spectroscopic data including 1D and 2D NMR, FTIR, UV and MS. These new alkaloids showed no cytotoxicity to HeLa, SGC-7901 gastric cancer, and A-549 lung cancer cell lines.

Keywords Cephalotaxus $\cdot$ Alkaloids · Cytotoxicity
\end{abstract}

\section{Introduction}

Various constituents of Cephalotaxus genus have been reported, including alkaloids [1-6], tropones [7-10], lignans [10, 11], diterpenes [9], flavonoids [6, 10]. Previous investigations led to approximate 100 Cephalotaxus alkaloids, which were mainly classified into two structural

Ling Ni and Xiu-Hong Zhong have contributed equally to this work.

Electronic supplementary material The online version of this article (doi:10.1007/s13659-016-0093-7) contains supplementary material, which is available to authorized users.

L. Ni · X.-H. Zhong · M.-F. Bao - B.-J. Zhang · J. Wu ·

X.-H. Cai $(\bowtie)$

State Key Laboratory of Phytochemistry and Plant Resources in West China, Kunming Institute of Botany, Chinese Academy of Sciences, Kunming 650201, People's Republic of China e-mail: xhcai@mail.kib.ac.cn

L. Ni · X.-H. Zhong · B.-J. Zhang · J. Wu University of Chinese Academy of Sciences, Beijing 100039, People's Republic of China

J. Cai

Germplasm Bank of Wild Species in Southwest China, Kunming Institute of Botany, Chinese Academy of Sciences,

Kunming 650201, People's Republic of China types, i.e., homoerythrina and cephalotaxine-type, and the latter demonstrated remarkable antitumor activities [12]. For example, homoharringtonine among cephalotaxine alkaloids was successfully used to treat acute leukemia. As for homoharringtonine, the side chains played an important role in the anticancer activity of these compounds which possessed H-3 $\alpha$-configuration. So far only reported cephalezomines $\mathrm{G}$ possessed H-3 $\beta$-configuration. Both homoerythrina and cephalotaxine had same biogenetic origin. However, most of homoerythrinas almost with H-3 $\alpha$-configuration reminded us that there were more cephalotaxines with same configuration. As a part of our continuous research for Cephalotaxus alkaloids, five new alkaloids, together with 24 known ones (Fig. 1) were isolated from leaves and twigs of $C$. lanceolata and $C$. fortune $i$ var. alpina. The known alkaloids were identified as drupacine (6) [2], cephalotaxinone (7) [13], acetycephalotaxine (8) [14], cephalezomine J (9) [5], desmethylcephalotaxine (10) [15], isocephalotaxinone (11) [16], 11-hydroxycephalotaxin (12) [2], cephalotaxine (13) [17], lucidinine (14) [18], comosidine (15) [18], schelhammeridine (16) [19], 3-epischelhammeridine (17) [20], comosine (18) [21], 3-epicomosine (19) [20], 3-epischelhammericine (20) [20], fortunine (21) [22], taxodine (22) [23], $O$-methylschlammericine (23) [13], cephalezomine M (24) [5], homoisoharringtonine (25) [24], homoharingtonine (26) [25], 

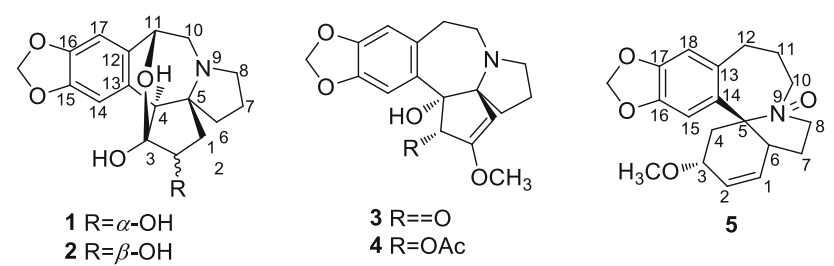

Fig. 1 Structures of alkaloids from C. lanceolata and C. fortunei var. alpine

isoharringtonine (27) [25, 26], epidesoxyharringtonine (28) [27], desoxyharringtonine (29) [28] by comparison with literatures.

\section{Results and Discussion}

Newly isolates (1-5) probably belong to alkaloids as they exhibited a positive reaction with Dragendorff's reagent. Alkaloid 1 was isolated as white powder. Its UV absorption bands at 203 and $291 \mathrm{~nm}$ and IR absorption bands at 3520, $3406,1631,1500,1482,1342 \mathrm{~cm}^{-1}$ were consistent with those of Cephalotaxus alkaloids [2]. Analysis of the ${ }^{1} \mathrm{H}$ and ${ }^{13} \mathrm{C}$ NMR data of 1 (Tables 1,2 ) revealed several typical functionalities similar to those of the known alkaloid drupacine (6) [2], including a tetrasubstituted benzene ring with two para $\mathrm{H}$-atoms $\left(\delta_{\mathrm{H}} 6.76, \delta_{\mathrm{C}} 110.1 ; \delta_{\mathrm{H}} 6.72, \delta_{\mathrm{C}}\right.$ $\left.106.0 ; \delta_{\mathrm{C}} 128.6,132.4,146.8,147.4\right)$, a $-\mathrm{OCH}_{2} \mathrm{O}-$ moiety $\left(\delta_{\mathrm{H}} 5.97 ; \delta_{\mathrm{C}} 101.5\right)$, a ketal carbon $\left(\delta_{\mathrm{C}} 106.7\right)$, two $O-$ bearing $\mathrm{CH}$ groups $\left(\delta_{\mathrm{H}} 3.86, \delta_{\mathrm{C}} 76.7 ; \delta_{\mathrm{H}} 4.81, \delta_{\mathrm{C}} 76.1\right)$, and two $-\mathrm{OH}$ groups $\left(\delta_{\mathrm{H}} 3.53\right.$ and 4.68$)$. The molecular formula of $\mathbf{1}$ was established as $\mathrm{C}_{17} \mathrm{H}_{19} \mathrm{NO}_{5}$ with nine degrees of unsaturation by HRESIMS $\left([\mathrm{M}+\mathrm{H}]^{+}\right.$at $\mathrm{m} / \mathrm{z}$ 318.1336), absence of a methyl than that of $\mathbf{6}$. The HMBC correlations (Fig. 2) of the methine signal $\left(\delta_{\mathrm{H}} 4.81\right)$ with $\mathrm{C}-12\left(\delta_{\mathrm{C}} 132.4\right), \mathrm{C}-13\left(\delta_{\mathrm{C}} 128.6\right)$, and $\mathrm{C}-17\left(\delta_{\mathrm{C}} 106.0\right)$ allowed its position as C-11. Likewise, the other signal $\delta_{\mathrm{H}}$ 3.38 was assigned to $\mathrm{CH}-4$ based on its $\mathrm{HMBC}$ correlations with $\delta_{\mathrm{C}} 110.1(\mathrm{C}-14), \mathrm{C}-12$ and $\delta_{\mathrm{C}} 39.2(\mathrm{C}-6)$. The obvious HMBC correlation between methylene protons $\left(\delta_{\mathrm{H}} 1.37\right.$ and 2.23) with $\mathrm{C}-6$ and $\mathrm{C}-3$ attributed it to $\mathrm{C}-1$. The proton signal $\delta_{\mathrm{H}} 3.86$ was assigned to $\mathrm{H}-2$ based on its correlation with $\delta_{\mathrm{H}} 2.23$ in the ${ }^{1} \mathrm{H}-{ }^{1} \mathrm{H}$ COSY (Fig. 2) spectrum. The ketal carbon $\left(\delta_{\mathrm{C}} 106.7\right)$ was located at C-3 by its HMBC correlations from H-1, 2 and 4. The HMBC crosspeak of H-11/C-3 showed an oxygen bridge between C-11/C-1 in 1 consistent with its degrees of unsaturation. $\mathrm{H}-2$ was established as $\beta$-orientation on the basis of the coupling constant $(\mathrm{d}, J=6.4 \mathrm{~Hz})$ of $\mathrm{H}-2$. Consequently, the structure of 1 was confirmed as shown in Fig. 1, and named cephalotine A.

Alkaloid 2 had the same molecular formula (HRESIMS $\left.\mathrm{m} / \mathrm{z} 318.1335[\mathrm{M}+\mathrm{H}]^{+}\right)$and very similar UV and IR spectra as $\mathbf{1}$. Comparison of the ${ }^{13} \mathrm{C}$ NMR data of $\mathbf{2}$ and $\mathbf{1}$ (Table 2) suggested that both compounds shared the same planar structure. In the ${ }^{1} \mathrm{H}$ NMR spectrum (Table 1), obvious difference between both alkaloids was that a proton signal $\delta_{\mathrm{H}} 3.86(\mathrm{~d}, J=6.4 \mathrm{~Hz}, \mathrm{H}-2)$ in 1 was replaced by $\delta_{\mathrm{H}} 4.05(\mathrm{t}, J=8.9 \mathrm{~Hz})$ in 2 . This indicated $\alpha$-configuration of $\mathrm{H}-2$ in $\mathbf{2}$, and confirmed by a ROESY correlation from $\mathrm{H}-2$ to H-4. Thus, 2 was established as 3-epicephalotine A and named cephalotine B.

Alkaloid 3 displayed similar ${ }^{1} \mathrm{H}$ and ${ }^{13} \mathrm{C}$ NMR data (Tables 1,2) to the known alkaloid cephalotaxinone (7) [13] except that a quaternary carbon $\left(\delta_{\mathrm{C}} 81.9\right)$ in 3 substituted a methine in 7. In addition, the HMBC correlations of both $\mathrm{H}-1$ and $\mathrm{H}-14$ with $\delta_{\mathrm{C}} 81.9$ located the quaternary carbon to C-4. The molecular formula $\mathrm{C}_{18} \mathrm{H}_{19} \mathrm{NO}_{5}$ of 3 from HRESIMS $\mathrm{m} / \mathrm{z}$ at $330.1337[\mathrm{M}+\mathrm{H}]^{+}, 16$ mass units higher than that of $\mathbf{7}$, further indicated that $\mathbf{3}$ was an 4-hydroxy cephalotaxinone. Alkaloid 4 showed the similar ${ }^{13} \mathrm{C}$ NMR data to the known alkaloid acetycephalotaxine (8) [14], except that a methine signal of $\mathbf{8}$ was substituted by a quaternary carbon $\delta_{\mathrm{C}} 86.1$ (s) in $\mathbf{4}$. Like in $\mathbf{3}$, the additional hydroxyl of $\mathbf{4}$ was also located at C-4 by its molecular formula $\mathrm{C}_{20} \mathrm{H}_{23} \mathrm{NO}_{6}$ by HRESIMS at $\mathrm{m} / \mathrm{z}$ $\left.374.1604[\mathrm{M}+\mathrm{H}]^{+}\right), 16$ mass units higher than that of 8 . Further, this was supported by the HMBCs of $\delta_{\mathrm{H}} 5.21$ (H1) and $\delta_{\mathrm{H}} 7.15(\mathrm{H}-14)$ with $\delta_{\mathrm{C}} 86.1(\mathrm{C}-4)$. The hydroxyl of 3 and $\mathbf{4}$ adopted $\alpha$-orientation by the molecular model. The configuration of H-3 in both alkaloids was $\alpha$-oriented by ROESY correlation between H-3 and H-11. Therefore, 3 and 4 were named cephalotines $\mathrm{C}$ and $\mathrm{D}$, respectively.

Six methylenes, 3 methines, a methyoxyl and 5 quaternary carbons in the ${ }^{13} \mathrm{C}$ NMR spectrum of alkaloid 5 revealed that $\mathbf{5}$ belongs to homoerythrina-type alkaloids rather than cephalotaxine-type alkaloids [2]. The ${ }^{13} \mathrm{C} N \mathrm{NM}$ and DEPT data of alkaloid 5 were similar to those of comosine (18) [21] with exception for three downfielded signals [87.0 (s), $67.6(\mathrm{t}), 63.3(\mathrm{t})]$, suggesting a $\mathrm{N}$-oxide moiety. Additionally, its molecular formula $\mathrm{C}_{20} \mathrm{H}_{23} \mathrm{NO}_{4}$ by HRESIMS $\left(\mathrm{m} / \mathrm{z} 330.1717[\mathrm{M}+\mathrm{H}]^{+}\right)$could support this presumption. The $\mathrm{H}-3$ was allowed at $\beta$-configuration through ROESY correlations of H-3 with $\mathrm{H}-10$ and $\mathrm{H}-12$. Thus 5 was named as cephalotine E.

None of these compounds showed any significant activity against HeLa, SGC-7901 gastric cancer, and A-549 lung cancer cell lines $\left(\mathrm{IC}_{50}>20 \mu \mathrm{M}\right)$.

\section{Experimental Section}

\subsection{General Experimental Procedures}

Optical rotations were carried out using a Horiba SEPA300 polarimeter and JASCO DIP-370 digital polarimeter. 
Table $1{ }^{1} \mathrm{H}$ NMR spectroscopic data of $\mathbf{1 - 5}(\delta$ in ppm and $J$ in $\mathrm{Hz})$

\begin{tabular}{|c|c|c|c|c|c|}
\hline Position & $\delta_{\mathrm{H}}(\mathbf{1})^{\mathrm{a}}$ & $\delta_{\mathrm{H}}(2)^{\mathrm{a}}$ & $\delta_{\mathrm{H}}(\mathbf{3})^{\mathrm{b}}$ & $\delta_{\mathrm{H}}(\mathbf{4})^{\mathrm{a}}$ & $\delta_{\mathrm{H}}(\mathbf{5})^{\mathrm{a}}$ \\
\hline \multirow[t]{2}{*}{1} & $1.37 \mathrm{~d}(15.0)$ & $1.70 \mathrm{dd}(14.4,8.4)$ & $6.69 \mathrm{~s}$ & $5.21 \mathrm{~s}$ & $6.12 \mathrm{~m}$ \\
\hline & $2.23 \mathrm{dd}(15.0,6.4)$ & $1.82 \mathrm{dd}(14.4,9.6)$ & & & \\
\hline 2 & $3.86 \mathrm{~d}(6.4)$ & $4.05 \mathrm{t}(8.9)$ & & & $5.74 \mathrm{~d}(10.2)$ \\
\hline 3 & & & - & $5.47 \mathrm{~s}$ & 2.88 overlap \\
\hline \multirow[t]{2}{*}{4} & $3.38 \mathrm{~s}$ & $3.10 \mathrm{~s}$ & - & - & 1.66 overlap \\
\hline & & & & & 2.92 overlap \\
\hline \multirow[t]{2}{*}{6} & 1.67 overlap & 1.58 overlap & $1.79 \mathrm{~m}$ & 1.65 overlap & 3.93 overlap \\
\hline & 1.69 overlap & $1.68 \mathrm{~m}$ & $2.20 \mathrm{dd}(11.4,4.2)$ & $2.30 \mathrm{~m}$ & \\
\hline \multirow[t]{2}{*}{7} & 1.55 overlap & 1.56 overlap & $1.64 \mathrm{~m}$ & 1.49 overlap & 1.70 overlap \\
\hline & 1.57 overlap & 1.58 overlap & $1.82 \mathrm{~m}$ & 1.63 overlap & $2.64 \mathrm{~m}$ \\
\hline \multirow[t]{2}{*}{8} & $2.28 \mathrm{~m}$ & $2.25 \mathrm{~m}$ & $2.80 \mathrm{~m}$ & 2.67 overlap & $3.54 \operatorname{td}(2.4,13.2)$ \\
\hline & $2.60 \operatorname{td}(8.8,3.6)$ & $2.59 \mathrm{~m}$ & 2.95 overlap & $2.95 \mathrm{~m}$ & $4.08 \mathrm{~m}$ \\
\hline \multirow[t]{2}{*}{10} & $2.55 \mathrm{~d}(12.3)$ & $2.65 \mathrm{~d}(12.2)$ & $2.61 \mathrm{dd}(11.4,7.8)$ & 2.65 overlap & $3.43 \mathrm{~d}(13.0)$ \\
\hline & $2.71 \mathrm{dd}(12.3,4.0)$ & $2.71 \mathrm{dd}(12.2,4.0)$ & $2.75 \mathrm{~m}$ & $2.70 \mathrm{~m}$ & 3.92 overlap \\
\hline \multirow[t]{2}{*}{11} & $4.81 \mathrm{~d}(3.1)$ & $4.87 \mathrm{~d}(3.8)$ & $2.37 \mathrm{~m}$ & $2.36 \mathrm{dd}(14.4,6.8)$ & 1.68 overlap \\
\hline & & & $2.49 \mathrm{dd}(15.0,7.8)$ & $3.12 \mathrm{~m}$ & $2.57 \mathrm{~m}$ \\
\hline \multirow[t]{2}{*}{12} & & & & & $2.77 \mathrm{dd}(5.8,15.7)$ \\
\hline & & & & & $3.31 \mathrm{td}(2.3,11.2)$ \\
\hline 14 & $6.76 \mathrm{~s}$ & $6.73 \mathrm{~s}$ & $7.31 \mathrm{~s}$ & $7.15 \mathrm{~s}$ & \\
\hline 15 & & & & & $6.62 \mathrm{~s}$ \\
\hline 17 & $6.72 \mathrm{~s}$ & $6.74 \mathrm{~s}$ & $6.63 \mathrm{~s}$ & $6.67 \mathrm{~s}$ & \\
\hline 18 & & & & & $6.67 \mathrm{~s}$ \\
\hline \multirow[t]{2}{*}{$\mathrm{OCH}_{2} \mathrm{O}$} & $5.97 \mathrm{~s}$ & $5.93 \mathrm{~d}(1.1)$ & $5.96 \mathrm{~s}$ & $5.93 \mathrm{~s}$ & $5.93 \mathrm{~s}$ \\
\hline & $5.93 \mathrm{~s}$ & $5.97 \mathrm{~d}(1.1)$ & $5.97 \mathrm{~s}$ & $5.96 \mathrm{~s}$ & $5.94 \mathrm{~s}$ \\
\hline $2-\mathrm{OH}$ & 3.53 br* & 3.45 br* & - & & \\
\hline $3-\mathrm{OH}$ & 4.68 br* & 4.65 br* & - & & \\
\hline $4-\mathrm{OH}$ & - & - & 5.11 & & \\
\hline $2-\mathrm{OCH}_{3}$ & - & - & $3.81 \mathrm{~s}$ & $3.66 \mathrm{~s}$ & \\
\hline $3-\mathrm{OCH}_{3}$ & & & & & $3.22 \mathrm{~s}$ \\
\hline $\mathrm{CH}_{3} \mathrm{CO}$ & - & - & - & $2.51 \mathrm{~s}$ & \\
\hline
\end{tabular}

Alkaloids 1, 2, 4 and 5 recorded in acetone- $d_{6} ; 3$ in DMSO- $d_{6}$

* Assignments may be interchanged

${ }^{\text {a }}$ Recorded at $400 \mathrm{MHz}$

${ }^{b}$ Recorded at $600 \mathrm{MHz}$

UV spectra were recorded on Shimadzu 2401Aspectrophotometer. IR Spectra were obtained on Brucker Tensor 27 infrared spectrophotometer with $\mathrm{KBr}$ pellets. ${ }^{1} \mathrm{H}$, ${ }^{13} \mathrm{C}$ and 2D NMR spectral data were measured on a Bruker Avance III-600, DRX-500, and AM-400 MHz spectrometers with $\mathrm{SiMe}_{4}$ as an internal standard. HRESIMS data were recorded on an Agilent G6230 TOF MS. Column chromatography (CC) was performed with silica gel (200-300 mesh, Qing-dao Haiyang Chemical Co., Ltd., Qingdao, China). RP-18 silica gel (20-45 $\mu$ m, Fuji Silysia Chemical Ltd., Japan). Fractions were monitored by TLC on silica gel plates (GF254, Qingdao Haiyang Chemical Co., Ltd.) and spots visualized with Dragendorff's reagent spray. MPLC was employed using a Buchi pump system coupled with RP-18 silica gel packed glass columns $(15 \times 230$ and $26 \times 460 \mathrm{~mm}$, respectively). HPLC system was carried out on a Waters HPLC system (Waters 1525E pumps, Waters 2996 photodiode array detector, Waters fraction collector II) using a analytical semipreparative or preparative Sunfire $\mathrm{C}_{18}$ column $(4.6 \times 150$, $10 \times 150$, and $19 \times 250 \mathrm{~mm}$, respectively).

\subsection{Plant Materials}

Leaves and stems of $C$. lanceolata and $C$. fortunei var. alpina were collected from Yunnan Province, P. R. China 
Table $2{ }^{13} \mathrm{C}$ NMR spectroscopic data of alkaloids $\mathbf{1}-\mathbf{5}$ ( $\delta$ in ppm)

\begin{tabular}{lrrrrr}
\hline Position & $\delta_{\mathrm{C}}(\mathbf{1})^{\mathrm{a}}$ & $\delta_{\mathrm{C}}(\mathbf{2})^{\mathrm{a}}$ & \multicolumn{1}{c}{$\delta_{\mathrm{C}}(\mathbf{3})^{\mathrm{b}}$} & \multicolumn{1}{c}{$\delta_{\mathrm{C}}(\mathbf{4})^{\mathrm{a}}$} & $\delta_{\mathrm{C}}(\mathbf{5})^{\mathrm{a}}$ \\
\hline 1 & $34.2 \mathrm{t}$ & $34.2 \mathrm{t}$ & $125.0 \mathrm{~d}$ & $101.2 \mathrm{~d}$ & $130.0 \mathrm{~d}$ \\
2 & $76.7 \mathrm{~d}$ & $77.0 \mathrm{~d}$ & $158.1 \mathrm{~s}$ & $155.2 \mathrm{~s}$ & $128.7 \mathrm{~d}$ \\
3 & $106.7 \mathrm{~s}$ & $104.0 \mathrm{~s}$ & $200.1 \mathrm{~s}$ & $83.1 \mathrm{~s}$ & $76.0 \mathrm{~d}$ \\
4 & $53.7 \mathrm{~d}$ & $55.1 \mathrm{~d}$ & $81.9 \mathrm{~s}$ & $86.1 \mathrm{~s}$ & $31.6 \mathrm{t}$ \\
5 & $67.4 \mathrm{~s}$ & $65.5 \mathrm{~s}$ & $71.0 \mathrm{~s}$ & $76.8 \mathrm{~s}$ & $87.0 \mathrm{~s}$ \\
6 & $39.2 \mathrm{t}$ & $38.6 \mathrm{t}$ & $34.0 \mathrm{t}$ & $35.8 \mathrm{t}$ & $43.3 \mathrm{~d}$ \\
7 & $20.6 \mathrm{t}$ & $20.1 \mathrm{t}$ & $20.0 \mathrm{t}$ & $20.1 \mathrm{t}$ & $27.1 \mathrm{t}$ \\
8 & $50.2 \mathrm{t}$ & $50.1 \mathrm{t}$ & $54.1 \mathrm{t}$ & $54.2 \mathrm{t}$ & $67.6 \mathrm{t}$ \\
10 & $55.1 \mathrm{t}$ & $54.9 \mathrm{t}$ & $47.8 \mathrm{t}$ & $48.1 \mathrm{t}$ & $63.3 \mathrm{t}$ \\
11 & $76.1 \mathrm{~d}$ & $76.2 \mathrm{~d}$ & $32.4 \mathrm{t}$ & $31.0 \mathrm{t}$ & $23.0 \mathrm{t}$ \\
12 & $132.4 \mathrm{~s}$ & $132.4 \mathrm{~s}$ & $130.7 \mathrm{~s}$ & $131.8 \mathrm{~s}$ & $35.6 \mathrm{t}$ \\
13 & $128.6 \mathrm{~s}$ & $128.5 \mathrm{~s}$ & $134.3 \mathrm{~s}$ & $133.4 \mathrm{~s}$ & $135.0 \mathrm{~s}$ \\
14 & $110.1 \mathrm{~d}$ & $110.0 \mathrm{~d}$ & $108.2 \mathrm{~d}$ & $108.0 \mathrm{~d}$ & $128.2 \mathrm{~s}$ \\
15 & $147.4 \mathrm{~s}$ & $146.8 \mathrm{~s}$ & $146.7 \mathrm{~s}$ & $144.9 \mathrm{~s}$ & $111.1 \mathrm{~d}$ \\
16 & $146.8 \mathrm{~s}$ & $147.3 \mathrm{~s}$ & $147.4 \mathrm{~s}$ & $145.6 \mathrm{~s}$ & $146.9 \mathrm{~s}$ \\
17 & $106.7 \mathrm{~d}$ & $106.0 \mathrm{~d}$ & $110.1 \mathrm{~d}$ & $109.2 \mathrm{~d}$ & $148.0 \mathrm{~s}$ \\
18 & & & & & $112.7 \mathrm{~d}$ \\
$\mathrm{OCH}_{2} \mathrm{O}$ & $101.5 \mathrm{t}$ & $101.5 \mathrm{t}$ & $101.8 \mathrm{t}$ & $100.6 \mathrm{t}$ & $102.4 \mathrm{t}$ \\
$2-\mathrm{OCH}_{3}$ & - & - & $57.5 \mathrm{q}$ & $56.9 \mathrm{q}$ & \\
$3-\mathrm{OCH}_{3}$ & & & & & $56.1 \mathrm{q}$ \\
$\mathrm{CH}_{3} \mathrm{CO}$ & - & - & - & $168.9 \mathrm{~s}$ & \\
$\mathrm{CH}_{3} \mathrm{CO}^{1}$ & & & & $20.2 \mathrm{q}$ & \\
\hline & & & & &
\end{tabular}

Alkaloids 1, 2, 4 and 5 recorded in acetone- $d_{6} ; 3$ in DMSO- $d_{6}$

${ }^{\text {a }}$ Recorded at $100 \mathrm{MHz}$

${ }^{b}$ Recorded at $150 \mathrm{MHz}$

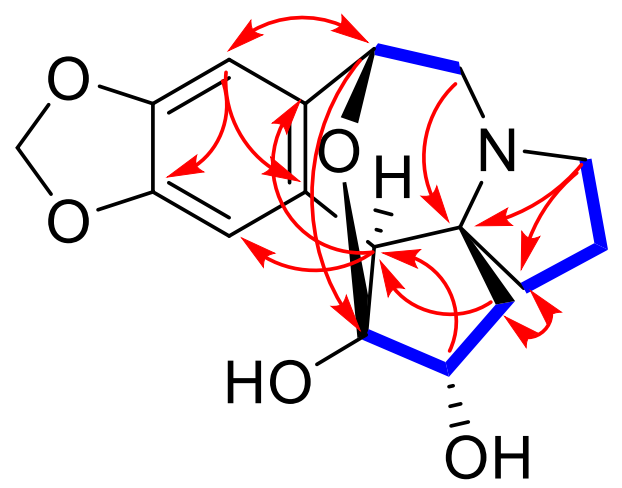

Fig. 2 Key ${ }^{1} \mathrm{H}-{ }^{1} \mathrm{H}$ COSY (-) and $\mathrm{HMBC}(\multimap)$ correlations of compound 1. (Color figure online)

and identified by Dr. Jie Cai, respectively. Two voucher specimen (cai20131002 and cai20140501) was preserved in the State Key Laboratory of Phytochemistry and Plant Resources in West China, Kunming Institute of Botany, Chinese Academy of Sciences.
3.3 Extraction and Isolation of $C$. lanceolata and $C$. fortunei var. alpina

The air-dried and powdered leaves and stems of $C$. lanceolata $(19 \mathrm{~kg})$ and $C$. fortunei var. alpina $(39 \mathrm{~kg})$ was extracted with $\mathrm{MeOH}(3 \times 50 \mathrm{~L}, 3 \times 100 \mathrm{~L}, 2$ days each $)$ at room temperature, respectively, and the solvent was evaporated in vacuo. The extract was dissolved in $1 \% \mathrm{HCl}$ solution (v/v) to $\mathrm{pH} 2-3$, basified with $10 \%$ ammonia solution (v/v) to $\mathrm{pH} \mathrm{7-8,} \mathrm{and} \mathrm{partitioned} \mathrm{with} \mathrm{EtOAc} \mathrm{to}$ afford the crude alkaloids (39 and $198 \mathrm{~g}$ ).

The alkaloidal extract of $C$. lanceolata (39 g) was subjected to $\mathrm{CC}$ over silica gel $(400 \mathrm{~g})$ and eluted with a $\mathrm{CHCl}_{3}-\mathrm{MeOH}$ gradient $(1: 0$ to $0: 1, \mathrm{v} / \mathrm{v})$ to give four fractions (I-IV) based on TLC analysis. Fraction I (7.5 g) was subjected to $\mathrm{C}_{18}$ MPLC with $\mathrm{MeOH}-\mathrm{H}_{2} \mathrm{O}$ (20:80 to $100: 0, \mathrm{~V} / \mathrm{V})$ as the eluent to obtain four fractions (I-1-I-4). I-1 (800 mg) was further separated on a $\mathrm{C}_{18}$ MPLC with a gradient of $\mathrm{MeOH}-\mathrm{H}_{2} \mathrm{O}$ (20:80 to 40:60, v/v) and then separated on a preparative $\mathrm{C}_{18}$ column with a gradient $\mathrm{MeOH}-\mathrm{H}_{2} \mathrm{O}$ (30:70 to 40:60, v/v) to afford 6 (30 mg). I-2 ( $3 \mathrm{~g}$ ) was purified on a $\mathrm{C}_{18}$ MPLC with a gradient of $\mathrm{MeOH}-\mathrm{H}_{2} \mathrm{O}(30: 20$ to $60: 40, \mathrm{v} / \mathrm{v})$ to afford the alkaloid 7 (8 mg). 11 (33 mg) was crystallized from I-3 (1 g), and the mother liquid of this fraction was separated on a $\mathrm{C}_{18}$ MPLC with a gradient of $\mathrm{MeOH}-\mathrm{H}_{2} \mathrm{O}$ (40:60 to 70:30, v/v) to afford the alkaloids 16 (18 mg) and 18 (14 mg). I-4 (2 g) was applied to a $\mathrm{C}_{18} \mathrm{HPLC}$ with a gradient of $\mathrm{MeOH}-\mathrm{H}_{2} \mathrm{O}$ (50:40 to $80: 10, \mathrm{v} / \mathrm{v}$ ) then separated on a preparative $\mathrm{C}_{18}$ column with a gradient $\mathrm{MeOH}-\mathrm{H}_{2} \mathrm{O}(55: 45$ to $65: 35)$ to obtain $17(20 \mathrm{mg}), \mathbf{2 0}(12 \mathrm{mg})$ and $21(5.5 \mathrm{mg})$. Fraction II (15 g) was applied to a $\mathrm{C}_{18}$ MPLC with a gradient of $\mathrm{MeOH}-\mathrm{H}_{2} \mathrm{O}(20: 80-100: 0, \mathrm{v} / \mathrm{v})$ to obtain four subfractions II-1-II-4. II-1 (5 g) was further applied to a $\mathrm{C}_{18}$ MPLC with a gradient of $\mathrm{MeOH}-\mathrm{H}_{2} \mathrm{O}(10: 90$ to $70: 30$, v/v) to give four fractions II-1-1-II-1-4. II-1-1 (0.8 g) was separated on a $\mathrm{C}_{18}$ MPLC with a gradient of $\mathrm{MeOH}-\mathrm{H}_{2} \mathrm{O}$ (10:90 to $30: 70, \mathrm{v} / \mathrm{v}$ ) and then separated on a preparative $\mathrm{C}_{18}$ column with a gradient $\mathrm{MeOH}-\mathrm{H}_{2} \mathrm{O}(25: 75$ to $35: 65$, v/v) to give 1 (8 $\mathrm{mg}$ ) and 2 (12.5 mg). II-1-3 (2 g) was subjected to a $\mathrm{C}_{18}$ MPLC with a gradient of $\mathrm{MeOH}-\mathrm{H}_{2} \mathrm{O}(30: 70$ to $60: 40$, v/v) and then separated on a preparative $\mathrm{C}_{18}$ column with a gradient $\mathrm{MeOH}-\mathrm{H}_{2} \mathrm{O}$ (48: 52 to $58: 42$, v/v) to give 12 (55 mg). II-3 $(4 \mathrm{~g})$ was applied to a $\mathrm{C}_{18}$ MPLC with a gradient of $\mathrm{MeOH}-\mathrm{H}_{2} \mathrm{O}$ (20:80 to 50:50, v/v) to obtain 27 ( $9.5 \mathrm{mg}$ ), and then separated on a preparative $\mathrm{C}_{18}$ column with a gradient $\mathrm{MeOH}-\mathrm{H}_{2} \mathrm{O}(38: 62$ to $48: 52$, v/v) to give 14 (11 mg). II-4 (3.0 g) was subjected to CC over silica gel $(30 \mathrm{~g})$ and eluted with a $\mathrm{CHCl}_{3}-\mathrm{MeOH}$ gradient $(25: 1$ to $15: 1, \mathrm{v} / \mathrm{v})$ and further purified on a preparative $\mathrm{C}_{18}$ column with a gradient $\mathrm{MeOH}-\mathrm{H}_{2} \mathrm{O}(50: 50$ to $60: 40, \mathrm{v} / \mathrm{v})$ to give 9 (14 mg). III (12 g) was applied to $\mathrm{C}_{18}$ MPLC with a 
gradient of $\mathrm{MeOH}-\mathrm{H}_{2} \mathrm{O}(20: 80$ to $60: 40$, v/v) to obtain four subfractions III-1-III-4. III-1 (4 g) was separated on a $\mathrm{C}_{18}$ MPLC with a gradient of $\mathrm{MeOH}-\mathrm{H}_{2} \mathrm{O}(10: 90$ to $40: 60, \mathrm{v} / \mathrm{v})$ to give 13 (10 mg). III-3 (2.5 g) was separated on a $\mathrm{C}_{18}$ MPLC with a gradient of $\mathrm{MeOH}-\mathrm{H}_{2} \mathrm{O}(30: 70$ to $60: 40, \mathrm{v} / \mathrm{v})$ to give 5 (10 $\mathrm{mg})$ and $\mathbf{2 2}(22 \mathrm{mg})$.

The alkaloidal extract of C. fortunei var. alpina (198 g) was subjected to $\mathrm{CC}$ over silica gel $(2.0 \mathrm{~kg})$, eluted with $\mathrm{CHCl}_{3}-\mathrm{MeOH}$ gradient (1:0 to $\left.0: 1, \mathrm{v} / \mathrm{v}\right)$ to yield six fractions (I-VI). Fraction II (43 g) was gradually purified $\mathrm{C}_{18}$ MPLC with $\mathrm{MeOH}-\mathrm{H}_{2} \mathrm{O}$ (30:70 to 100:0, V/V), to afford subfractions II-1-II-6. 6 (200 mg) was crystallized from II$1(7 \mathrm{~g})$, and the mother liquid of this fraction was separated on a $\mathrm{C}_{18}$ MPLC with a gradient of $\mathrm{MeOH}-\mathrm{H}_{2} \mathrm{O}$ (30:70 to $50: 50, \mathrm{v} / \mathrm{v})$ to afford $7(5 \mathrm{mg})$. II-3 (11 g) was subjected to $\mathrm{CC}$ over silica gel (120 g) with $\mathrm{CHCl}_{3}-\mathrm{Me}_{2} \mathrm{CO}(20: 1$ to $5: 1$, $\mathrm{v} / \mathrm{v}$ ) as the eluent and then further purified on a $\mathrm{C}_{18}$ MPLC with a gradient of $\mathrm{MeOH}-\mathrm{H}_{2} \mathrm{O}$ (30:70 to 50:50, v/v) to afford 3 (5 mg). II-4 (8 g) was gradually purified on a $\mathrm{C}_{18}$ MPLC $\left(\mathrm{MeOH}-\mathrm{H}_{2} \mathrm{O}, 40: 60\right.$ to $60: 40$, v/v) to afford 20 (98 mg) and then further purified on a preparative $\mathrm{C}_{18}$ column with a gradient $\mathrm{MeOH}-\mathrm{H}_{2} \mathrm{O}$ (48: 52 to 58:42, v/v) to give 21 (17 mg). II-5 (7 g) was separated by $\mathrm{C}_{18}$ MPLC with a gradient of $\mathrm{MeOH}-\mathrm{H}_{2} \mathrm{O}(50: 50$ to $70: 30$, v/v) to give 23 (39 mg). Fraction III (41 g) was separated on a $\mathrm{C}_{18}$ MPLC with a gradient of $\mathrm{MeOH}-\mathrm{H}_{2} \mathrm{O}(20: 80$ to $100: 0$, v/v) to afford subfractions (III-1-III-5). Subfraction III-3 (12 g) was gradually separated on a $\mathrm{C}_{18}$ MPLC, eluted with MeOH- $\mathrm{H}_{2} \mathrm{O}$ (30:70 to 50:50, v/v) to afford 14 (141 mg). 12 (133 mg) was crystallized from III-5 (13 g), and the mother liquid of this fraction was separated on a $\mathrm{C}_{18}$ MPLC with a gradient of $\mathrm{MeOH}-\mathrm{H}_{2} \mathrm{O}$ (20:80 to 40:60, v/v) to afford 10 (32 mg). IV (31 g) was separated on a $\mathrm{C}_{18}$ MPLC with a gradient of $\mathrm{MeOH}-\mathrm{H}_{2} \mathrm{O}$ (10:90 to $100: 0$, v/v) to yield subfractions IV-1-IV-9. IV-2(8 g) was further purified on a $\mathrm{C}_{18}$ MPLC with $\mathrm{CH}_{3} \mathrm{CN}-\mathrm{H}_{2} \mathrm{O}(5: 95$ to $15: 85$, v/v) as the eluent to give 7 (200 mg). IV-3 (3 g) was subjected to a $\mathrm{C}_{18}$ MPLC with $\mathrm{MeOH}-\mathrm{H}_{2} \mathrm{O}$ (20:80 to 50:50, v/v), then further purified on a preparative $\mathrm{C}_{18}$ column with a gradient $\mathrm{MeOH}-\mathrm{H}_{2} \mathrm{O}$ (35:65 to 45:55, v/v) to give 26 (46) and 27 (18 mg). 25 (54 mg) was crystallized from IV-5 (13 g). IV9 (5 g) was gradually separated on a $\mathrm{C}_{18}$ MPLC, eluted with $\mathrm{MeOH}-\mathrm{H}_{2} \mathrm{O}(35: 65$ to $55: 45, \mathrm{v} / \mathrm{v})$ to afford $28(100 \mathrm{mg})$ and 29 (380 mg). V (25 g) was subjected to a $\mathrm{C}_{18}$ MPLC with a gradient of $\mathrm{MeOH}-\mathrm{H}_{2} \mathrm{O}(10: 90$ to $100: 0$, v/v) to give five subfractions (V-1-V-5). V-2 (4 g) was separated on a $\mathrm{C}_{18}$ MPLC with a gradient of $\mathrm{MeOH}-\mathrm{H}_{2} \mathrm{O}$ (10:90 to 30:70, $\mathrm{v} / \mathrm{v})$ to afford $4(600 \mathrm{mg})$. VI $(17 \mathrm{~g})$ was purified on $\mathrm{C}_{18}$ MPLC with a gradient of $\mathrm{MeOH}-\mathrm{H}_{2} \mathrm{O}(10: 90$ to $100: 0, \mathrm{v} / \mathrm{v})$, and VI-3 (3 g) was gradually purified on a $\mathrm{C}_{18}$ MPLC $\left(\mathrm{MeOH}-\mathrm{H}_{2} \mathrm{O}, 10: 90\right.$ to $\left.30: 70, \mathrm{v} / \mathrm{v}\right)$ and further purified on a preparative $\mathrm{C}_{18}$ column with a gradient $\mathrm{MeOH}-\mathrm{H}_{2} \mathrm{O}$ (15: 85 to $25: 75, \mathrm{v} / \mathrm{v})$ to yield 15 (4 mg), $24(5 \mathrm{mg})$ and $\mathbf{1 9}(18 \mathrm{mg})$.
Cephalotine A (1): white powder; $[\alpha]_{\mathrm{D}}^{25}-31.5$ (c 0.09 , $\mathrm{MeOH}) ; \mathrm{UV}(\mathrm{MeOH}) \lambda_{\max }(\log \varepsilon) 203$ (3.01), 291 (3.91) $\mathrm{nm}$; IR (KBr) $v_{\max } 3520,3406,1631,1500,1482$, $1342 \mathrm{~cm}^{-1} ;{ }^{1} \mathrm{H}(400 \mathrm{MHz})$ and ${ }^{13} \mathrm{C}$ NMR (100 MHz) data (acetone- $d_{6}$ ), see Tables 1 and 2 ; positive HRESIMS $\mathrm{m} / z$ 318.1336 (calcd for $\mathrm{C}_{17} \mathrm{H}_{20} \mathrm{NO}_{5}[\mathrm{M}+\mathrm{H}]^{+}, 318.1342$ ).

Cephalotine B (2): white powder; $[\alpha]_{\mathrm{D}}^{25}-35.8$ (c 0.12 , $\mathrm{MeOH}) ; \mathrm{UV}(\mathrm{MeOH}) \lambda_{\max }(\log \varepsilon) 204$ (2.95), 291 (3.81) $\mathrm{nm}$; IR (KBr) $v_{\max } 3450,3430,1631,1484,1342 \mathrm{~cm}^{-1} ;{ }^{1} \mathrm{H}$ $(400 \mathrm{MHz})$ and ${ }^{13} \mathrm{C} \mathrm{NMR}(100 \mathrm{MHz})$ data (acetone- $\left.d_{6}\right)$, see Tables 1 and 2; positive HRESIMS $m / z \quad 318.1335$ (calcd for $\mathrm{C}_{17} \mathrm{H}_{20} \mathrm{NO}_{5}[\mathrm{M}+\mathrm{H}]^{+}, 318.1342$ ).

Cephalotine C (3): brown oil; $[\alpha]_{\mathrm{D}}^{25}+9.0$ (c 0.13 , $\mathrm{MeOH}) ; \mathrm{UV}(\mathrm{MeOH}) \lambda_{\max }(\log \varepsilon) 237(3.67), 280$ (3.80) $\mathrm{nm}$; IR (KBr) $v_{\max } 3437,2954,1752,1735,1654$, $1223 \mathrm{~cm}^{-1}$; ${ }^{1} \mathrm{H}(600 \mathrm{MHz})$ and ${ }^{13} \mathrm{C}$ NMR $(150 \mathrm{MHz})$ data (DMSO- $d_{6}$ ), see Tables 1 and 2 ; positive HRESIMS $\mathrm{m} / z$ 330.1337 (calcd for $\mathrm{C}_{18} \mathrm{H}_{20} \mathrm{NO}_{5}[\mathrm{M}+\mathrm{H}]^{+}, 330.1336$ ).

Cephalotine D (4): colorless powder; $[\alpha]_{\mathrm{D}}^{25}+138.0$ (c 0.41, MeOH); UV (MeOH) $\lambda_{\max }(\log \varepsilon) 240$ (3.84), 279 (3.89) nm; IR (KBr) $v_{\max } 3437,2922,1659,1590$, $1130 \mathrm{~cm}^{-1}$; ${ }^{1} \mathrm{H}(400 \mathrm{MHz})$ and ${ }^{13} \mathrm{C}$ NMR (100 MHz) data (acetone- $d_{6}$ ), see Tables 1 and 2; positive HRESIMS $\mathrm{m} / \mathrm{z}$ 374.1604 (calcd for $\mathrm{C}_{20} \mathrm{H}_{24} \mathrm{NO}_{6}[\mathrm{M}+\mathrm{H}]^{+}, 374.1598$ ).

Cephalotine E (5): white powder; $[\alpha]_{\mathrm{D}}^{25}+46.3$ (c 0.10 , $\mathrm{MeOH})$; UV (MeOH) $\lambda_{\max }(\log \varepsilon) 204$ (3.66), 243 (2.73), 288 (2.67)nm; IR (KBr) $v_{\max } 3419,2934,1623,1507$, $1490 \mathrm{~cm}^{-1} ;{ }^{1} \mathrm{H}(400 \mathrm{MHz})$ and ${ }^{13} \mathrm{C}$ NMR $(100 \mathrm{MHz})$ data (acetone- $d_{6}$ ), see Tables 1 and 2; positive HRESIMS $\mathrm{m} / z$ 330.1717 (calcd for $\mathrm{C}_{20} \mathrm{H}_{24} \mathrm{NO}_{4}[\mathrm{M}+\mathrm{H}]^{+}, 330.1705$ ).

\subsection{Cytotoxicity Assay}

Three human cancer cell lines, HeLa, SGC-7901 gastric cancer, and A-549 lung cancer, were used in the cytotoxicity assay. All the cells were cultured in RPMI-1640 or DMEM media (Hyclone, USA), supplemented with $10 \%$ fetal bovine serum (Hyclone, USA) in $5 \% \mathrm{CO}_{2}$ at $37{ }^{\circ} \mathrm{C}$. The cytotoxicity assay was performed according to the MTT (3-(4,5-dimethylthiazol-2-yl)-2,5-diphenyl tetrazolium bromide) method in 96-well microplates. Briefly, $100 \mu \mathrm{L}$ adherent cells were seeded into each well of 96-well cell culture plates and allowed to adhere for $12 \mathrm{~h}$ before addition of the test compound/drug. Meanwhile suspended cells were seeded with initial density of $1 \times 10^{5}$ cells/mL just before addition of the test compound/drug. Each tumor cell line was exposed to the test compound at concentrations of $0.06,0.32,1.60,8.0$, and $40 \mu \mathrm{M}$ for $48 \mathrm{~h}$. Each of these tests was conducted in triplicate, with cisplatin (sigma, USA) as the positive control. After the end of the treatment period, cell viability was measured and cell growth curve was plotted. 
Acknowledgments This project was financially supported by the Young Academic and Technical Leader Raising Foundation of Yunnan Province (No. 2010CI049).

\section{Compliance with Ethical Standards}

Conflict of Interest The authors declare no conflict of interest.

Open Access This article is distributed under the terms of the Creative Commons Attribution 4.0 International License (http:// creativecommons.org/licenses/by/4.0/), which permits unrestricted use, distribution, and reproduction in any medium, provided you give appropriate credit to the original author(s) and the source, provide a link to the Creative Commons license, and indicate if changes were made.

\section{References}

1. W.W. Paudler, G.I. Kerley, J. McKay, J. Org. Chem. 28, 2194 (1963)

2. R.G. Powell, R.V. Madrigal, C.R. Smith Jr, K.L. Mikolajczak, J. Org. Chem. 39, 676 (1974)

3. I. Takano, I. Yasuda, M. Nishijima, Y. Hitotsuyanagi, K. Takeya, H. Itokawa, Bioorg. Med. Chem. Lett. 6, 1689 (1996)

4. H. Morita, M. Arisaka, N. Yoshida, Tetrahedron 56, 2929 (2000)

5. H. Morita, M. Yoshinaga, J.I. Kobayashi, Tetrahedron 58, 5489 (2002)

6. L.W. Wang, H.J. Su, S.Z. Yang, S.J. Won, C.N. Lin, J. Nat. Prod. 67, $1182(2004)$

7. J.G. Buta, J.L. Flippen, W.R. Lusby, J. Org. Chem. 43, 1002 (1978)

8. J. Du, M.H. Chiu, R.L. Nie, J. Nat. Prod. 62, 1664 (1999)
9. Y.R. He, Y.H. Shen, L. Shan, X. Yang, B. Wen, J. Ye, X. Yuan, H.L. Li, X.K. Xu, W.D. Zhang, RSC Adv. 5, 4126 (2015)

10. K.D. Yoon, D.G. Jeong, Y.H. Hwang, J.M. Ryu, J. Kim, J. Nat. Prod. 70, 2029 (2007)

11. K.D. Yoon, Y.W. Chin, J.W. Kim, Bull. Korean Chem. Soc. 31, 495 (2010)

12. H. Abdelkafi, B. Nay, Nat. Prod. Rep. 29, 845 (2012)

13. R. Powell, Phytochemistry 11, 1467 (1972)

14. R. Powell, D. Weisleder, C. Smith, J. Pharm. Sci. 61, 1227 (1972)

15. R. Powell, K. Mikolajczak, Phytochemistry 12, 2987 (1973)

16. S. Asada, Yakugaku Zasshi 93, 916 (1973)

17. R. Powell, D. Weisleder, C. Smith, I. Wolff, Tetrahedron Lett. 10, 4081 (1969)

18. N. Langlois, J. Razafimbelo, J. Nat. Prod. 51, 499 (1988)

19. J.S. Fitzgerald, S. Johns, J. Lamberton, A. Sioumis, Aust. J. Chem. 22, 2187 (1969)

20. S. Johns, J. Lamberton, A. Sioumis, Aust. J. Chem. 22, 2219 (1969)

21. L. Lacombe, N. Langlois, B. Das, P. Potier, Bull. Soc. Chim. Fr. 10, 3535 (1970)

22. M.H. Qiu, B.P. Lu, X. Ma, R.L. Nie, Acta Botanica Yunnanica 19, 99 (1997)

23. F. Chang, C. Wang, W. Pan, Y. Li, L. Mai, C. Sun, K. Ma, J. Integr. Plant Biol. 20, 129 (1978)

24. S. Li, Y. Cui, Y. Li, X. Pan, Y. Wang, W. Hung, Acta Chim. Sinica 45, 687 (1987)

25. R. Powell, D. Weisleder, C. Smith, W. Rohwedder, Tetrahedron Lett. 11, 815 (1970)

26. S.B. Li, Y.X. Cui, X.Y. Nie, X.X. Pan, Y.L. Li, Sci. Bull. 33, $1436(1988)$

27. W.K. Huang, Y.L. Li, X.X. Pan, Sci. China Ser. A 23, 835 (1980)

28. K. Mikolajczak, R. Powell, C. Smith, Tetrahedron 28, 1995 (1972) 